17. Iusypiva T., Miasoid G. The Impact of Industrial Pollution with Toxic Gases on Stem Histological Parameters of Woody Plant Undergrowth under Conditions of the Southern Industrial Zone of the City of Dnipro, Ukraine // International Letters of Natural Sciences. Vol. 59. P. 62-71.

18. Impacts of ozone on forests: a European perspective / L. Skärby et al. // New Phytol. 1998. 139. P. 109-122.

Надійшла до редколегії 14.06.2016 p.

УДК 581.1

Н. Ф. Павлюкова, Т. В. Легостасва

Дніпропетровський національний університет імені Олеся Гончара

\title{
ЗМІНИ АНАТОМО-МОРФОЛОГІЧНИХ ПОКАЗНИКІВ РОСЛИН РОДУ ACER L. В УМОВАХ м. ДНІПРО
}

Вивчено видоспецифічні особливості анатомо-морфологічних показників однорічних пагонів представників роду Acer L. Показано різницю параметрів гістологічних елементів пагонів дерев, що зростають на узбіччі автострад, та дерев з умовно чистої зони. Виявлено пряму залежність між розмірами короку, первинної і вторинної кори та здатністю дерев протидіяти антропогенному впливу. Встановлено, що за анатомічною будовою найбільш толерантним до впливу техногенних емісій виявився $A$. pseudoplatanus L., найбільш чутливим - A. negundo L.

Ключові слова: Acer pseudoplatanus L., Acer platanoides L., Acer negundo L., урбанізоване середовище, гістологічні показники.

\section{Н. Ф. Павлюкова, Т. В. Легостаева}

Днепропетровский национальный университет имени Олеся Гончара

\section{ИЗМЕНЕНИЯ АНАТОМО-МОРФОЛОГИЧЕСКИХ ПОКАЗАТЕЛЕЙ РАСТЕНИЙ РОДА ACER L. В УСЛОВИЯХ Г. ДНЕПРА}

Изучены видоспецифические особенности анатомо-морфологических показателей однолетних побегов представнителей рода $A c e r$ L. Показана разница параметров гистологических элементов побегов деревьев, которые произрастают на обочине автострад, и деревьев из условно чистой зоны. Выявлена прямая зависимость между размерами пробки, первичной и вторичной коры и способностью деревьев противостоять антропогенному воздействию. Установлено, что по анатомическому строению наиболее толерантным к влиянию техногенных емиссий оказался $A$. pseudoplatanus L., найболее чувствительным - A. negundo $\mathrm{L}$.

Ключевые слова: Acer pseudoplatanus L., Acer platanoides L., Acer negundo L., урбанизированная среда, гистологические показатели.

\author{
N. F. Pavlyukova, T. V. Legostayeva \\ Oles Honchar Dnipropetrovsk National University
}

\section{CHANGES OF ANATOMICAL AND MORPHOLOGICAL INDEXES OF ACER L. KIN PLANTS IN THE CONDITIONS OF DNIPRO CITY}

The species-specific features of anatomic-morphological indexes of one-year escapes of representatives of sort of Acer $\mathbf{L}$. are studied. Shown difference of parameters of histological elements of escapes of trees that grow on the side of a road of motorways and trees from a conditionally clean zone. Educed direct dependence between the sizes of bark, primary and secondary bark and by ability of trees to counteract to anthropogenic influence. It is

(C) Н. Ф. Павлюкова, Т. В. Легостаєва, 2016 
set that after an anatomic structure to influence of technogenic emissions An appeared the most tolerant $A$. pseudoplatanus L., most sensible $-A$. negundo $\mathrm{L}$.

Keywords: Acer pseudoplatanus L., Acer negundo L., Acer platanoides L., urban environment, histological indexes.

У зв’ язку з антропогенним навантаженням, розвитком урбанізації набуває актуальності ідея створення насаджень паркового типу і моделювання штучних ценозів, в яких деревним рослинам відводиться головна роль, а сучасні тенденції ландшафтного дизайну відображають намагання підвищити естетико-психологічну комфортність міського середовища за допомогою озеленення.

Для успішного вирішення цих завдань необхідне широке залучення дендрологічних ресурсів, проведення аналізу успішності інтродукційних випробувань найбільш цінних у декоративному та господарському відношенні видів. Зелені насадження $\epsilon$ ефективними засобами для поліпшення середовищно-захисних, санітарно-гігієнічних і естетичних умов у ландшафтній архітектурі [5]. Інтродукція деревних рослин спрямована на вирішення як фундаментальних проблем, пов'язаних iз збереженням біорізноманіття флори, виявленням закономірностей адаптації деревних рослин в умовах нового ареалу, так і практичних задач по найбільш повному і раціональному використанню рослинних ресурсів, зокрема при вирішенні проблеми фітооптимізації урбанізованого середовища, підвищення його ландшафтно-архітектурних і санітарних властивостей за рахунок використання, поряд 3 аборигенними рослинами, найбільш стійких інтродуцентів [6].

Об'єкти та методи дослідження. Об'єктом наших досліджень обрано деякі види роду Acer L., а саме - Acer pseudoplatanus L., Acer platanoides L., Acer negundo L. Для визначення анатомо-морфологічних показників 3 дорослих рослин кленів відбирали однорічні пагони у вересні 2014 р. 3 різних моніторингових точок м. Дніпра: I - автомагістраль вздовж проспекта ім. Газети «Правда»; II - автомагістраль вздовж проспекта Героїв; контролем слугували пагони, зібрані на території ботанічного саду ДНУ, де за даними міської санепідстанції, концентрація забруднюючих речовин не перевищує ГДК. Гістологічні показники рослин визначалися за загальноприйнятою методикою [7].

Дослідження проведені в триразовій повторності, результати опрацьовані за допомогою пакета Microsoft Statistica 6.0. Розбіжності між вибірками вважали значущими при $p \leq 0,05$.

Результати дослідження. Клени є важливою складовою дендрологічної структури усіх категорій міських зелених насаджень і на достатньо високому рівні виконують фітомеліоративну функцію [3]. Відомо, що рослини поглинають токсиканти і пил, покращуючи тим самим склад повітря. Проте полютанти негативно впливають на рослинний організм, змінюючи спрямованість метаболізму рослин, що, у свою чергу, відбивається на перебігу фізіолого-біохімічних реакцій, анатомічній структурі, насіннєвому відтворенні тощо [1].

Найбільш чутливими до вищевказаних факторів є молоді тканини вегетативних органів. Так, встановлено, що однорічні пагони реагують на забрудненість повітря змінами гістологічної будови [2]. Таким чином, дослідження анатомічної будови однорічних пагонів має важливе значення для оцінки життєздатності та стійкості рослин до умов росту на промислових територіях та слугує перспективним діагностичним параметром [4].

Анатомічна будова пагона зумовлена його функціями, які виконує система покривних, провідних, механічних та запасаючих тканин органа. Тому вона типова для усіх деревно-чагарникових рослин, але у ступені розвитку тих чи інших тканин має і певні відмінності, які визначаються видовими особливостями рослин і є результатом впливу зовнішнього середовища.

Результати досліджень наведено у табл. 1-3. 
Товщина пагонів та співвідношення різних гістологічних елементів у різних видів кленів у контрольній точці у вересні є неоднаковим, що вказує на видову специфічність цих показників. Так, діаметр пагона найбільший у Acer pseudoplatanus L. - 4406,12 мкм, порівняно з 3802,70 мкм - у Acer platanoides L. та 3681,30 мкм - у Acer negundo L., у якого він найменший. Корок та первинна кора найбільш розвинені у Acer pseudoplatanus L. - у сумі 11,8 \% від радіуса пагона. У Acer negundo L. цей показник складає 11 \%, у Acer platanoides L. 9,5\%. Натомість відсоткове співвідношення серцевини до діаметра пагона найбільше у Acer negundo L. - 60 \%, у Acer platanoides L. - дещо менше (55 \%), у Acer pseudoplatanus L. - найменше (52\%).

Гістологічними елементами вторинної кори є м'який луб та твердий луб. Серед досліджуваних видів найбільшу товщину вторинної кори мають однорічні пагони Acer pseudoplatanus L. та Acer negundo L. (8,7 \% та 8,5 \% від радіуса пагона відповідно), тоді як у Acer platanoides L. вона становить $6 \%$.

Виміри товщини камбію показали, що на долю цього елемента припадає приблизно однаковий відсоток в усіх досліджуваних видів - приблизно 0,5 \% від радіуса пагона. Далі до центра пагона розташована деревина з паренхімними серцевинними променями. Відсоток деревини до радіуса пагонів Acer pseudoplatanus L., Acer platanoides L. та Acer negundo L. складає 29 \%, 27 \% та 20 \% відповідно.

Табличя 1

Показники анатомічної будови пагонів Acer negundo L. у вересні

\begin{tabular}{|c|c|c|c|c|c|c|c|c|c|}
\hline \multirow{3}{*}{$\begin{array}{c}\text { Гістологічні } \\
\text { елементи }\end{array}$} & \multicolumn{9}{|c|}{ Місця відбору проб } \\
\hline & \multicolumn{3}{|c|}{ Контроль (бот. сад) } & \multicolumn{3}{|c|}{$\begin{array}{c}\text { I - пр. ім. Газети } \\
\text { «Правда» }\end{array}$} & \multicolumn{3}{|c|}{ II - пр. Героїв } \\
\hline & \multicolumn{9}{|c|}{ Ширина гістологічних елементів, мкм } \\
\hline Корок & 27,61 & \pm & 1,38 & 28,60 & \pm & 1,43 & 29,20 & \pm & 1,46 \\
\hline Первинна кора & 174,86 & \pm & 8,74 & 173,25 & \pm & 8,66 & 171,17 & \pm & 8,56 \\
\hline Вторинна кора & 156,45 & \pm & 7,82 & 155,95 & \pm & 7,80 & 155,70 & \pm & 7,79 \\
\hline Камбій & 9,20 & \pm & 0,46 & 9,10 & \pm & 0,46 & 9,30 & \pm & 0,47 \\
\hline Деревина & 368,13 & \pm & 18,41 & 332,13 & \pm & 16,61 & 333,16 & \pm & 16,66 \\
\hline Серцевина & 2208,78 & \pm & 110,44 & 2185,23 & \pm & 109,26 & 2175,61 & \pm & 108,78 \\
\hline Діаметр пагона & 3681,30 & \pm & 184,07 & 3583,29 & \pm & 179,16 & 3572,67 & \pm & 178,63 \\
\hline
\end{tabular}

Примітка. Похибка вимірювання не перевищує 5 \% від середніх значень.

Показники анатомічної будови пагонів Acer platanoides L. у вересні

Таблиия 2

Сloказники анатомічноі будови narotiв Acer platanoides L. y вересні

\begin{tabular}{|c|c|c|c|c|c|c|c|c|c|}
\hline \multirow{3}{*}{$\begin{array}{l}\text { Гістологічні } \\
\text { елементи }\end{array}$} & \multicolumn{9}{|c|}{ Місця відбору проб } \\
\hline & \multicolumn{3}{|c|}{ Контроль (бот.сад) } & \multicolumn{3}{|c|}{$\begin{array}{c}\mathrm{I}-\text { пр. ім. Газети } \\
\text { «Правда» }\end{array}$} & \multicolumn{3}{|c|}{ II - пр. Героїв } \\
\hline & \multicolumn{9}{|c|}{ Ширина гістологічних елементів, мкм } \\
\hline Корок & 51,34 & \pm & 2,57 & 56,17 & \pm & 2,81 & 58,87 & \pm & 2,94 \\
\hline Первинна кора & 129,29 & \pm & 6,46 & 130,82 & \pm & 6,54 & 128,16 & \pm & 6,41 \\
\hline Вторинна кора & 114,08 & \pm & 5,70 & 115,41 & \pm & 5,77 & 113,60 & \pm & 5,68 \\
\hline Камбій & 9,50 & \pm & 0,48 & 9,52 & \pm & 0,48 & 9,60 & \pm & 0,48 \\
\hline Деревина & 551,39 & \pm & 27,57 & 498,92 & \pm & 24,95 & 496,26 & \pm & 24,81 \\
\hline Серцевина & 2091,48 & \pm & 104,57 & 2086,17 & \pm & 104,31 & 2072,11 & \pm & 103,61 \\
\hline Діаметр пагона & 3802,70 & \pm & 190,14 & 3707,85 & \pm & 185,39 & 3685,09 & \pm & 184,25 \\
\hline
\end{tabular}

Примітка. Похибка вимірювання не перевищує 5 \% від середніх значень. 
У центрі пагонів досліджуваних видів кленів розташовано серцевину. Розміри iï клітин зменшуються, а товщина клітинних оболонок зростає в напрямку від центра серцевини до периферії - в перимедулярній зоні. Найбільших розмірів серцевина набуває в Acer negundo L. - 60 \% від загального діаметра пагона, найменших Acer pseudoplatanus L. - 52 \%, у Acer platanoides L. - середнє значення - 55 \%.

Показники анатомічної будови пагонів Acer pseudoplatanus L.

Таблиия 3

\begin{tabular}{|l|ccc|ccc|ccc|}
\hline \multirow{3}{*}{$\begin{array}{c}\text { Гістологічні } \\
\text { елементи }\end{array}$} & \multicolumn{8}{|c|}{ Місця відбору проб } \\
\cline { 2 - 10 } & Контроль (бот.сад) & \multicolumn{7}{c|}{$\begin{array}{c}\text { I - пр. } \\
\text { ім. Газети «Правда» }\end{array}$} & \multicolumn{2}{c|}{ II - пр. Героїв } \\
\cline { 2 - 10 } & \multicolumn{8}{|c|}{ Ширина гістологічних елементів, мкм } \\
\hline Корок & 44,06 & \pm & 2,20 & 60,82 & 3,04 & 62,13 & \pm & 3,11 \\
\hline Первинна кора & 215,89 & \pm & 10,79 & 257,42 & \pm & 12,87 & 259,34 & \pm & 12,97 \\
\hline Вторинна кора & 191,67 & \pm & 9,58 & 240,82 & \pm & 12,04 & 239,15 & \pm & 11,96 \\
\hline Камбій & 11,02 & \pm & 0,55 & 10,90 & \pm & 0,55 & 11,07 & \pm & 0,55 \\
\hline Деревина & 594,82 & \pm & 29,74 & 529,62 & \pm & 26,48 & 528,17 & \pm & 26,41 \\
\hline Серцевина & 2291,20 & \pm & 114,56 & 2198,19 & \pm & 109,91 & 2192,40 & \pm & 109,62 \\
\hline Діаметр пагона & 4406,12 & \pm & 220,31 & 4397,35 & \pm & 219,87 & 4392,12 & \pm & 219,61 \\
\hline
\end{tabular}

Примітка. Похибка вимірювання не перевищує 5 \% від середніх значень.

Таким чином, дослідні види відрізняються співвідношенням тканин, що складають пагін. Розглядаючи корок та первинну кору як захисний бар'єр для проникнення негативних зовнішніх факторів (шкідливих речовин), можна зробити висновок, що у Acer pseudoplatanus L. і Acer platanoides L. найбільшу захисну роль виконує корок та первинна кора. Завдяки відносно високому розвитку цих тканин, вищевказані види найбільш пристосовані до запобігання проникнення шкідливих полютантів всередину пагонів рослин. Натомість Acer negundo L. та Acer platanoides L. мають збільшений розмір серцевини порівняно 3 Acer pseudoplatanus L., що, як відомо, $є$ пристосувальним фактором до несприятливих умов (як місце запасання поживних речовин), завдяки чому ці рослини більш підготовлені до стану спокою.

Далі розглянемо як впливають урботехногенні фактори на розвиток тканин пагонів роду Acer L. на дослідних ділянках. Порівняємо показники розмірів тканин у дослідних точках I (пр. ім. газети «Правда») та II (пр. Героїв), де мають місто викиди $\mathrm{CO}_{2}, \mathrm{SO}_{2}, \mathrm{CO}$, важких металів та інших полютантів 3 контрольною точкою в ботанічному саду, де вміст токсичних речовин менший за ГДК.

На дію промислових викидів різні види кленів реагують неоднаково, гістологічні зміни спостерігаємо практично в усіх елементах анатомічної будови однорічних пагонів.

Так, добре простежується тенденція збільшення розміру короку під впливом полютантів у всіх видів кленів. Найпомітніше зростання товщини короку у видів 3 дослідних ділянок спостерігається у Acer pseudoplatanus L. У цього виду захисний шар перидерми під впливом токсичних викидів у точках I і II збільшується на $38 \%$ та $41 \%$ відповідно.

Порівняно менше реагують на дію полютантів збільшенням короку у моніторингових точках Acer platanoides L. - 9,4 \% (I точка) та 14,7 \% (II точка) та Acer negundo L. - 3,6 \% (I точка) та 5,8 \% (II точка).

Відносний розмір первинної та вторинної кори у дослідних точках практично не зменшувався у видів Acernegundo L. та Acer platanoides L. У Acer pseudoplatanus L. спостерігається збільшення цих структур: в середньому на $20 \%$ порівняно 3 контролем збільшується первинна кора, та в середньому на 25 \% збільшується вторинна кора. 
Товщина камбію в усіх дослідних точках та в усіх видів практично була постійною.

Розміри деревини під урботоксичним впливом зменшувалися в моніторингових точках усіх видів у середньому на 10 \% порівняно з контролем.

Ще більш незначним було зменшення серцевини (в середньому на 1 \% порівняно з контролем).

Загальний діаметр пагонів у дослідних точках незначно зменшувався у Acer platanoides L. i Acer negundo L. (в середньому на 2,6 \% в I точці та на 3 \% у II точці). У Acer pseudoplatanus L. це зменшення було зовсім незначним - до 0,3 \% порівняно $з$ контролем. На зменшення діаметра пагонів більше вплинуло зменшення розмірів серцевини та деревини, ніж збільшення короку, первинної та вторинної кори, які мають значно меншу частку у будові пагонів.

Таким чином, вплив полютантів на рослини в дослідних точках змінює їх гістологічну структуру.

Так, у Acer pseudoplatanus L. спостерігається значне потовщення короку, первинної та вторинної кори порівняно з контрольною точкою. Це вказує на те, що Acer pseudoplatanus L. добре пристосовується до шкідливого впливу полютантів. Збільшення розмірів захисних тканин запобігає подальшому проникненню токсичних елементів вглиб пагона.

Зменшення розміру деревини в усіх дослідних видах в моніторингових точках може порушувати пересування розчинів органічних речовин і елементів мінерального живлення по системі спеціалізованих провідних тканин, i, таким чином, підвищувати вразливість рослин роду Acer L. на техногенних територіях.

Зменшення діаметра серцевини за дії фітотоксикантів, скоріш за все, відбувається за рахунок збільшення частки інших гістологічних елементів (короку, первинної та вторинної кори).

За сукупністю анатомічних характеристих однорічного пагона із досліджених видів більшу чутливість до впливу техногенних емісій виявляє Acer negundo L. та Acer platanoides L., а толерантність - Acer pseudoplatanus L.

Порівнюючи гістологічні зміни в пагонах кленів у першій та другій точках, можна зробити висновок, що у другій точці усі види рослин зазнавали більшого техногенного впливу, ніж у першій точці.

\section{Висновки.}

Аналіз отриманих результатів гістохімічних експрес-аналізів дозволяє зробити висновки стосовно певних адаптивних властивостей рослин Acer negundo L., Acer platanoides L., Acer pseudoplatanus L. Товщина пагона та співвідношення різних гістологічних елементів є видоспецифічними ознаками. Техногенні викиди призводять до гістологічних змін в усіх елементах анатомічної будови однорічних пагонів кленів. Пристосувальними до антропогенного впливу ознаками можна вважати збільшення короку, первинної та вторинної кори, що запобігає подальшому проникненню токсичних елементів вглиб пагона. 3 усіх досліджуваних видів найбільш пристосованим до впливу техногенних факторів за гістологічною структурою виявився Acer pseudoplatanus L. Найбільш чутливим до техногенних емісій за анатомічною будовою виявився Acer negundo L.

\section{Бібліографічні посилання}

1. Голикова М. М. Вплив промислового забруднення на елементи анатомічної структури пагонів кленів // Вісник Львів. ун-ту. Сер. біологічна. 2011. Вип. 57. С. 242-248.

2. Грицай 3. В. Показники анатомічної будови первинної кори стебла однорічного пагона деревних рослин в умовах техногенного навантаження // Рослини та урбанізація. Дніпропетровськ. 2007. С. 118-119.

3. Зайцева I. О., Голикова М. М. Особливості водного режиму кленів за умов гідротермічного стресу та техногенного навантаження // Питання біоіндикації та екології. 2010. Вип. 15. № 1. С. 53-63. 
4. Кохно Н.А., Курдюк А. М. Теоретические основы и опыт интродукции древесных растений в Украине. Киев. 1994. 185 с.

5. Лапин П. И. О терминах, применяемых в исследованиях по интродукции и акклиматизации растений // Бюлл. ГБС. 2002. Вып. 83. С. 10-18.

6. Поляков $\boldsymbol{A}$. $\boldsymbol{K}$. Интродукция древесных растений в услових техногенной среды. Донецк. 2009. 268 с.

7. Прозина М. Н. Ботаническая микротехника. Москва. 1960. 206 с.

Надійшла до редколегії 21.03.2016

УДК $581.2+581.522 .4$

\title{
T. І. Юсипіва
}

Дніпропетровський національний університет імені Олеся Гончара

\author{
ВПЛИВ ПРОМИСЛОВИХ ВИКИДІВ $\mathrm{SO}_{2} \mathrm{TA} \mathrm{NO}_{2}$ \\ НА МОРФОМЕТРИЧНІ ПОКАЗНИКИ САМОСІВУ \\ TA ПIДРОCTУ ROBINIA PSEUDOACACIA L.
}

Вивчено дію промислових емісій $\mathrm{SO}_{2}$ та $\mathrm{NO}_{2}$ на біометричні показники стебла самосіву та однорічного пагона підросту Robinia pseudoacacia L. в умовах степового Придніпров'я. Виявлено, що за дії на рослини робінії псевдоакації токсичних газів відбуваються зміни інтенсивності росту осьових органів і асиміляційного апарату. Запропоновано чутливі тест-параметри (довжина головного кореня, площа листка та асиміляційної поверхні самосіву) для фітоіндикації стану молодих рослин $\boldsymbol{R}$. pseudoacacia в техногенних умовах зростання.

Ключові слова: самосів, підріст, біометричні показники, токсичні гази $\mathrm{SO}_{2} \mathrm{Ta}_{2}$.

\section{Т. И. Юсыпива}

Днепропетровский национальный университет имени Олеся Гончара

\section{ВЛИЯНИЕ ПРОМЫШЛЕННЫХ ВЫБРОСОВ $\mathrm{SO}_{2}$ И NO НА МОРФОМЕТРИЧЕСКИЕ ПОКАЗАТЕЛИ САМОСЕВА И ПОДРОСТА ROBINIA PSEUDOACACIA L.}

Изучено влияние промышленных эмиссий $\mathrm{SO}_{2}$ и $\mathrm{NO}_{2}$ на биометрические показатели стебля самосева и однолетнего побега подроста Robinia pseudoacacia L. в условиях степного Приднепровья. Показано, что под действием на растения робинии псевдоакации токсических газов происходят изменения интенсивности роста осевых органов и ассимиляционного аппарата. Предложены чувствительные тест-параметры (длина главного корня, площадь листа и ассимиляционной поверхности самосева) для фитоиндикации состояния молодых растений $R$. pseudoacacia в техногенных условиях произрастания.

Ключевые слова: самосев, подрост, биометрические показатели, токсические газы $\mathrm{SO}_{2}$ и $\mathrm{NO}_{2}$.

T. Iusypiva

Oles Honchar Dnipropetrovsk National University

INFLUENCE OF INDUSTRIAL SO, AND NO $\mathrm{NO}_{2}$ EISSIONS ON MORPHOMETRIC PARAMETERS OF ROBINIA PSEUDOACACIA L. SELF-SOWN PLANTS AND UNDERGROWTH

The paper examines the influence of industrial $\mathrm{SO}_{2}$ and $\mathrm{NO}_{2}$ emissions on biometric parameters of Robinia pseudoacacia L. self-sown plant and one-year un-

(C) Т. І. Юсипіва, 2016 